\title{
圧電素子を用いた非拘束センサシステムによる離床行動予測*
}

\author{
間所 洋和 ${ }^{* 1}$ ，下井 信浩 ${ }^{* 1}$, 佐藤 和人 ${ }^{* 1}$
}

\section{Unrestrained Sensor Systems Using Piezoelectric Elements for Bed-Leaving Prediction}

\author{
Hirokazu MADOKORO *1, Nobuhiro SHIMOI and Kazuhito SATO \\ ${ }^{* 1}$ Faculty of Systems Science and Technology, Akita Prefectural University \\ 84-4, Tsuchiya Aza Ebinokuchi, Yurihonjo City, Akita, 015-0055, Japan
}

This paper presents a sensor system to predict behavior patterns that occur when patients leave their beds. We originally developed plate-shaped sensors using piezoelectric elements. Existing sensors such as clip sensors and mat sensors require restraint of patients. Moreover, these sensors present privacy problems. The features of our sensors are that they require no power supply or patient restraint. We evaluated our system using a basic experiment to predict seven behavior patterns with machine-learning algorithms without setting thresholds. We obtained a result of predicted behavior patterns related to bed-leaving using only six sensors installed under a bed. Especially, our system can correctly detect behavior patterns of lateral sitting, which is a position that occurs when a patient tries to leave from the bed, and terminal sitting, which is the position immediately before bed-leaving. They were discerned from other behavior patterns.

Key Words : Piezoelectric Elements, Bed Leaving, Self-Organizing Maps, Counter Propagation Networks

1. は じめに

2010 年に実施された国勢調査によると，我が国は高齢者か総人口の $23.1 \%$ を占める超高齢社会に突入している 更に, 2015 年には, 4 人に 1 人が 65 歳以上の高齡者になることが予想されている ${ }^{(1)}$. 介護施設等においては, 少 ないスタッフで多数の入居者を介護するため, 就寝中や仮眠中の管理が手薄になることが問題になっている ${ }^{(2)}$. こ のため，離床時の転落防止対策として，離床センサを用いた予防策が施されている施設か増えている(3) (4) . 表 1 に， 現在の離床検出に使用されている代表的なセンサの特徵を，コスト，検出タイミング, 精度 , プライバシ , 及び拘 束性の観点から比較した .

最も安価で容易に導入できるセンサとして，クリップセンサが挙げられる．被介護者の衣服に取り付けるだけ の, 最も単純で簡単なセンサである ${ }^{(5)}$. 一方, 被介護者の人権擁護の観点から, 近年は拘束を伴うクリップセンサ の使用を控えることが求められている . また , センサの性能面では, クリップセンサは離床の検出を ON/OFF の 2 值で判断するため, 誤作動や異常検知が多発する.このため, システムの信頼性や管理面で, 被介護者の転倒や 転落事故を十分に防止できていないことが懸念されている.更に, クリップコードが首に巻き付く事故も発生し ており ${ }^{(5)}$, 安価で導入が容易であるものの，臨床現場で使用するには信頼性が得られる十分なセンサと言えない， 低価格でかつ非拘束型のセンサとして , マット型のセンサが普及している(6). 春山らは, マットセンサを用いた 離床検知通報装置を開発している ${ }^{(7)}$. また , 各種メーカから , 床やベッドの表面, 手摺などに装着するマットセン サか販売されている．床に敷くセンサは，医療機器としての認定が不要なことから，最も容易に製造・販売でき るが, 性能面では端座位以降の判定になるため, 検出の遅れが問題となっている．また，看護師等の医療従事者 がマット上を通過した場合にも反応し，両者の区別が困難になることもある . 手摺に巻き付けて装着するセンサ は，外観を損ねるばかりでなく，被介護者がセンサに気付いて意図的に取り外すことや，手摺に触れずに離床を

\footnotetext{
* 原稿受付 2013 年 1 月 22 日

*1 正員, 秋田県立大学システム科学技術学部

（ ( 015-0055＼cjkstart秋田県由利本荘市土谷字海老ノ口 84-4）

E-mail: madokoro@akita-pu.ac.jp
} 
Table 1 Comparison of characteristics of existing bed-leaving sensors.

\begin{tabular}{c|c|c|c|c|c}
\hline Sensor type & Cost & Timing & Accuracy & Privacy & Restriction \\
\hline Clip & Low & Fast & Low & High & Yes \\
\hline Bed mat & Low & Fast & Low & Low & No \\
\hline Floor mat & Low & Slow & Low & Low & No \\
\hline Handrail & Low & Fast & Low & Low & No \\
\hline Camera & High & Fast & High & High & No \\
\hline Infrared & High & Fast & High & High & No \\
\hline Supersonic & High & Fast & High & High & No \\
\hline Strain gauge & High & Fast & Low & Low & No \\
\hline
\end{tabular}

した場合の検出漏れが問題となる.ベッド上に敷くタイプのセンサは, 最も安定して離床を検出することができ るが , 断線等の問題がある .このように, 既存のセンサは, クリップセンサと同樣に 2 值の単純な応答に頼って いるのか現状であり，離床行動の早期段階では検出が困難となっている．

離床の早期予測と被介護者の行動パターンを詳細に計測するために，特性が異なる複数のセンサを用いた大規 模システムが提案されている．清水らは，超音波アレイセンサを用いた離床検出システムを開発し，臨床現場での 評価を実施している ${ }^{(11)}$. 平澤らは, 転倒転落事故防止システムとして, ベッド上部に赤外線を照射する方式を提 案している(12) . 上薗らは, 格子状に配置した 96 個の歪ゲージを用いて, 離床に関係する被験者の行動パターンを 検出している(13) . これらのセンサシステムは, クリップセンサやマットセンサと比較して, 高精度で安定した検 出と判定を実現しているが, 装置が高価なため, 実用化には至っていないのか現状である . また , 仮に実用化に向 けて開発が進んだとしても，行動判定に時間を要することや設置に伴うコストや工事等の新たな課題に直面する 初雁らは，ひずみゲージをアクチュエータに装着して，ベッド上での荷重変化から離床を検出するシステムを 実用化している(14) . 離床 CATCH という商品名で自社のパラマウントベッドに組み込まれており，起き上がりと 端座位の検知率が $87.0 \%$ と $98.1 \%$ という性能を示している . システム構成としては, ベッド 1 台に 3 本アクチュ エータが装着されており，各アクチュエータの対角線上に 2 軸のひずみゲージを 4 個ずつ張り付けている . 現状 では, 精度及び信頼性の高い実用的な離床センサであると評価できる．しかしながら，アクチュエータ付きの昇 降型ベッド以外は用いることができない . また , アクチュエータ付きのベッドを製造する際に , コントローラを 含めてセンサを組み込む必要がある .このため, 導入にはベッド本体を購入しなければならず, 後付けにより手軽 に利用できるセンサではない，また，初雁らが用いているひずみゲージは，温度保障付きではない，温度変化に よる特性の違いはソフトウェアで対応していると述べられているものの，判定は 3 段階に区分された体重別の閾 值による処理に留まっている．

カメラを用いたモニタリングは，センサ及びシステムが比較的安価であり，豊富な情報が得られる，一方，画像 のみから被介護者の行動パターンを判定することは，現在のコンピュータビジョンの最新技術を用いても，困難 でかつ挑戦的な課題とされている.このため，現状は第三者による監視が必要となり，多数の被介護者を同時に 管理できない . また , プライバシの侵害にも関わるため, 人権問題や生活の質 (Quality of Life: QOL) に関係す る事項も解決しなければならない，特に，離床行動の認識においては，人光れ光れの行動パターンが異なるため， 単純なセンサ応答だけでは, 詳細な解析を実施しても判定が困難となることが報告されている ${ }^{(9)}$. また，カメラで 始終監視されていることから，被介護者にとっては，精神的な負担となっている．

このような問題を解決するために，本論文では，圧電素子を用いた非拘束型の離床予測センサを提案する．ま た，マイコンを搭載した計測システムと機械学習による閾値の設定を必要としない判定手法を構筑を目的とする． 本研究では, 使用するセンサの個数を最小限に留めることにより, 離床予測時におけるデータ量の低減と誤認識 の減少を目指す．圧電素子を用いる本センサは, 計測用の電源を必要としないという利点を有するとともに, 温 度変化による影響を受けないため，簡易でかつ安定したセンシングが実現できる．臨床現場を模した環境での評 価実験では，7 種類の行動パターンが判定できるとともに，特に離床予測に結びつく長座位と端座位の判定におい て，実応用に資する結果と知見が得られたので報告する． 


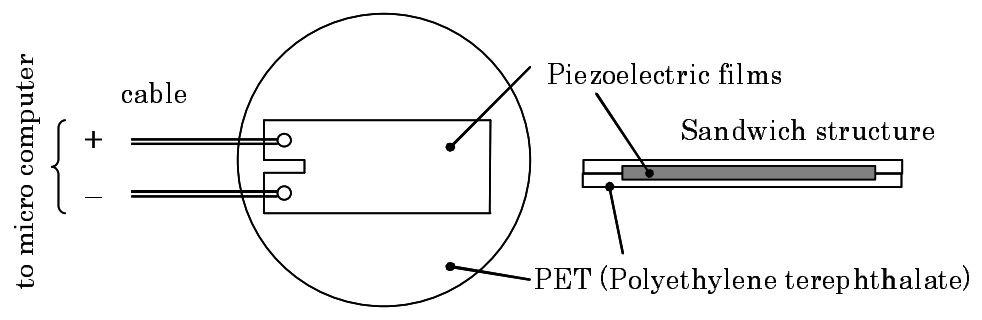

(a) Upper view

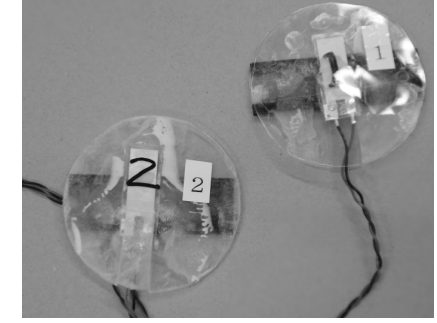

(c) developed sensors

Fig. 1 Design and developed sensors

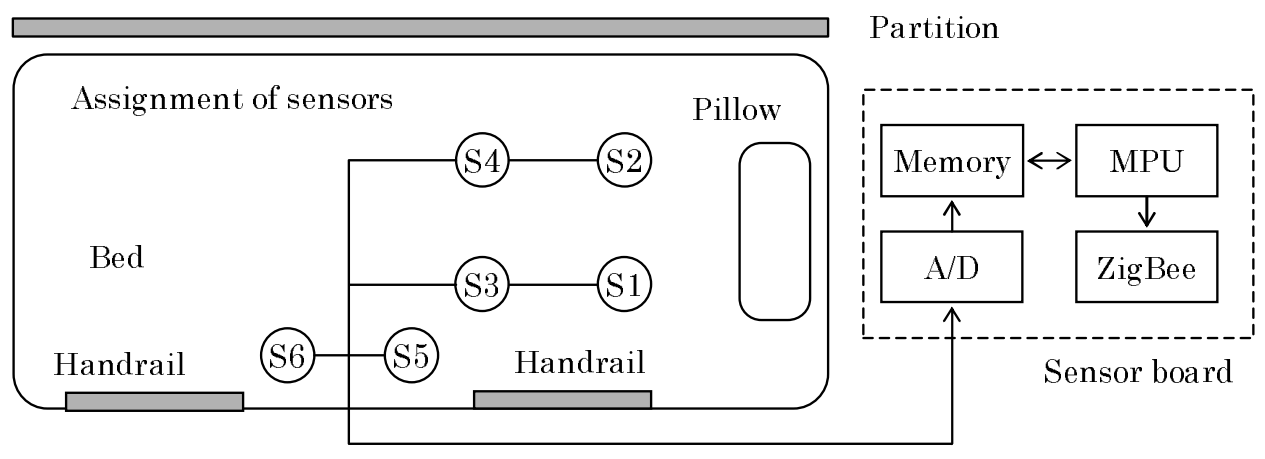

Signal cable ( 6 channels)

Fig. 2 Block diagram of our proposed system and assignment of pat sensors on the bed. S1-S6 denote sensor positions.

\section{2. 離床予測センサシステム}

$2 \cdot 1$ パッドセンサ

従来の離床予測やベッドモニタリングシステムでは, 高性能で高機能な多種多樣のセンサを設置して , 高額な 介護や医療を対象とした複雑なシステムが構築されていた ${ }^{(7)(11) \sim(13)}$.一方, 本研究では, 実用性を考慮して , コ ストと利便性を重視した設計とした . 具体的には, ベッドや布団の下に容易に設置できるように , シーツの下に 敷くパッド形状のオリジナルの荷重認識センサを考案した 。

本センサは , 東京センサ社製のフィルム形状の圧電素子 ${ }^{(10)}$ を用いて試作した . ポリエステルにラミネート加工 を施して一体化した 2 枚のペット板に, 圧電素子を挟み込み, エポキシ樹脂で接着固定した .なお, ポリエステル の厚さは $125 \mu \mathrm{m}$ ，ペット板の大きさは $\phi 70 \times 0.5 \mathrm{~mm}$ とした . 試作したパッドセンサの構造及び外観を図 1 に示す .

寝返り等によりベッド上の被験者の荷重か移動した場合, 圧電素子が変形し電圧が出力される.基準電位はフィ ルムに変形が生じる度にオフセットが入るため, 繰り返し測定が可能となる . また, 圧電素子の変形量と出力電 圧は比例関係を示すため, 姿勢変化に伴う荷重の強度をリニアに得ることができる．更に，圧電素子は測定用の 電源を必要としないため, 配線が単純になり, 故障や誤作動が少ない . また, 電池交換等のメンテナンスも不要で あることから，実用的なシステムの提供が可能になると考えられる．

\section{$2 \cdot 2$ システム構成}

本研究で開発するセンサシステムの全体構成を図 2 に示す . 本システムは, ベッド上に布置するパッド型荷重 センサ 6 枚と, 各センサからの出力電圧を取得し , 無線通信によりモニタリング用端末に送信するためのマイコ ンを搭載したボードから構成される。

本センサは, 被験者の寝返りや起床による体重移動に伴う荷重の変化を受けて, 圧電素子に変形が生じて電圧が 発生する.このセンサを，図 2 に示すように肩部（センサ：S1，S2）, 剧部（センサ：S3，S4），及び昇降部(セ ンサ : S5，S6) の6 箇所に配置した . なお, 洗濯も可能なようにファスナテ -プを用いて下敷きパッドに固定し 


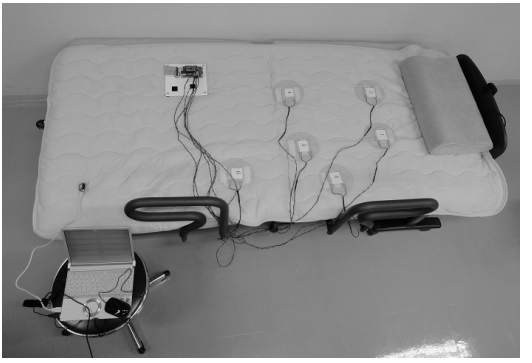

(a) Whole system

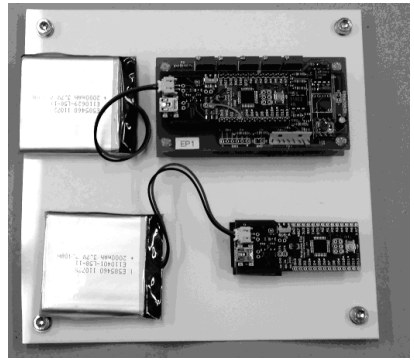

(b) Sensor boards

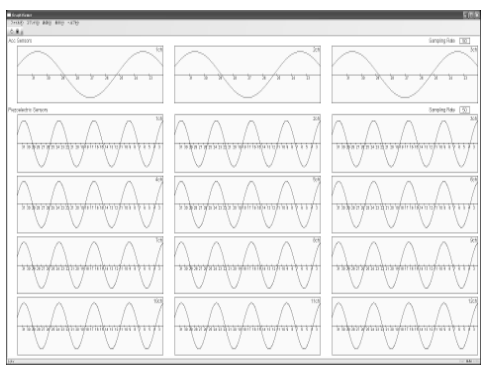

(c) Monitoring software

Fig. 3 Photographs of our sensor system.

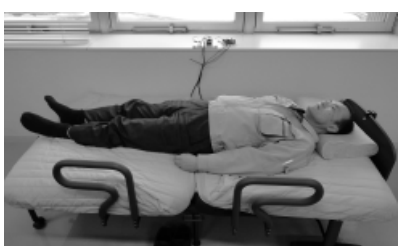

(1) Upper

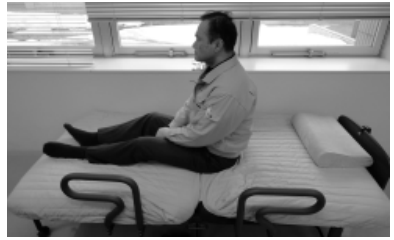

(4) Longitudinal

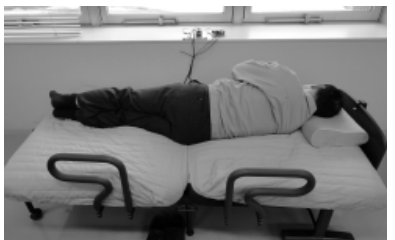

(2) Right

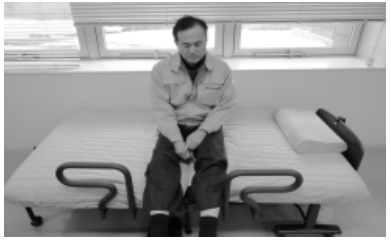

(5) Lateral

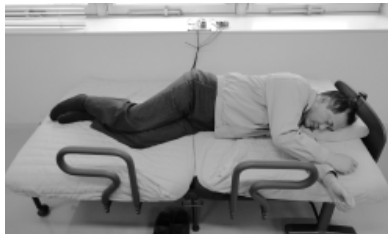

(3) Left

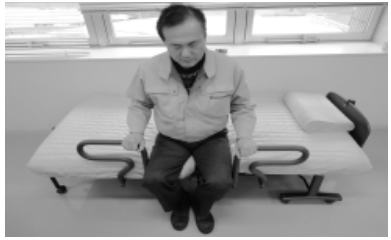

(6) Terminal

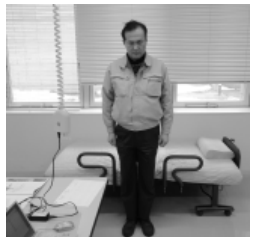

(7) Leaved

Fig. 4 Photographs of target patterns in each body position on the bed.

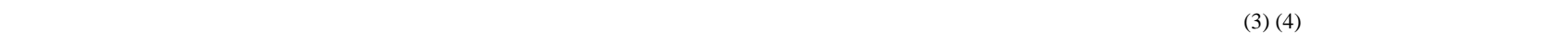

本システムの特長は, クリップ等の拘束型センサや赤外線カメラ等により被験者を監視するのではなく，QOL を尊重した通常の生活と変わりがない非拘束センサによるモニタリングを実現することにある.更に，電源を必要 とせず，耐圧にも優れた故障や誤作動の少ない圧電素子をセンサとして用いることで, 低価格のシステム構築が実 現できる . センサから出力された電圧は, 有線でマイコンボ - ドに入力される . 図 3(b) にマイコンボードの外観 を示す . 本ボードは, オープンソースハードウェアの ArduinoFIO を用いてシステムを構築した . マイコンボード と解析用端末の通信は, 消費電力を考慮して近距離無線通信規格の ZigBee を用いた . なお， 1 枚のマイコンボドには最大 4 チャネルまでのセンサ入力が可能であり，測定には 2 枚のマイコンボ - ドを使用して最大 8 チャネ ルに対応している。

ZigBee で送信された測定データは，パソコン等のモニタリング用端末でリアルタイムに表示される．モニタリ ング用ソフトウェアの画面を図 3(c) に示す . 本システムでは , モニタリング端末に機械学習のアルゴリズムを組 み込み，離床の判定を行った。

\section{3. 離 床判 定方式}

\section{$3 \cdot 1$ 判定対象パターン}

離床の判定は, 大別して, 就寝中, 離床行動, 完全離床の 3 パターンが対象となる. 本研究では, 6 枚のパッド センサの反応パターンから, 更に細分化した姿勢の判定を試みる . 就寝中は, 仰向けに寝ている姿勢 (仰臥位) と, 左右に寝返りを打っている姿勢（右臥位, 左臥位）の3パターンから構成される.離床予測の対象となる行動は, 被験者が起き上がりベッドの長手方向に着座している状態 (長座位) , 昇降口に向かって体を横に回転させてべッ ドの短手方向に向かって着座している状態 (短座位) , ベッド端付近の昇降口まで体を移動して離床を試みようと している状態 (端座位) の 3 パターンに分類することができる ${ }^{(16)}$. 以上の 6 パターンに完全離床状態を加えたも 


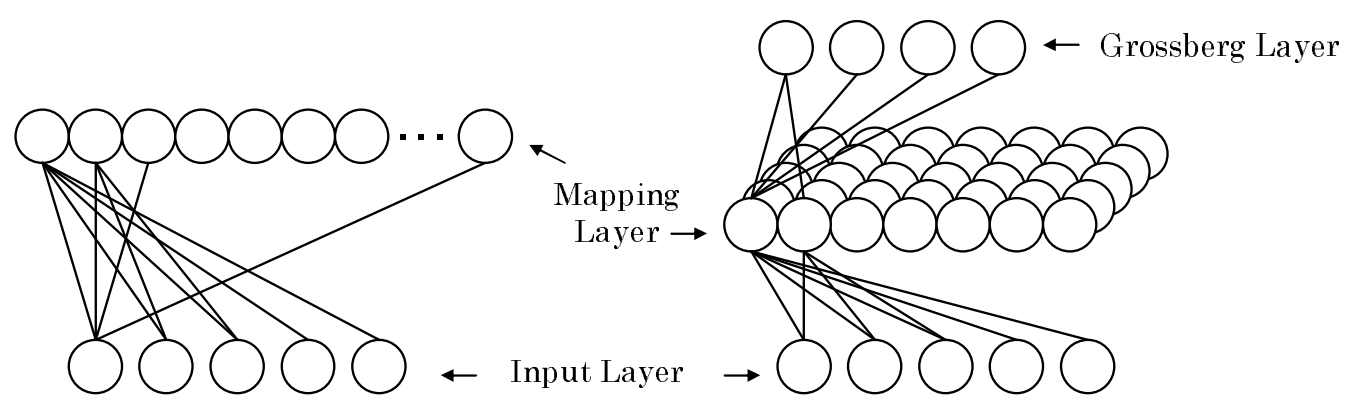

(a) Self-Organizing Maps

(b) Counter Propagation Networks

Fig. 5 Network architecture of SOM and CPN.

のを，本研究における判定対象とする . 姿勢別の判定対象パターンの写真を図 4 に示す . 以下に , 各姿勢の特徵 と想定されるセンサの反応パターンについて要点をまとめる .

(1) 仰臥位 被験者が仰向けになって就寝している状態 .ベッドの昇降口付近に布置した S5，S6 の出力がなく， 上半身の体圧が加わる S1〜S4 に荷重変化か想定される．

(2) 右臥位 被験者が右側を向いて就寝している状態 .ベッド右側に布置した S1，S3 に荷重変化が想定される.

(3) 左臥位 被験者が左側を向いて就寝している状態 .ベッド左側に布置した S2，S4 に荷重変化か想定される． ここまでは就寝中の姿勢となる．

（4）長座位 被験者が起床し, ベッドの長手方向に着座している状態. 布置した S3，S4 に臂部からの荷重変化が 想定される .ここからか離床予測の対象姿勢となる．

(5) 短座位 被験者か離床に向けた動作を試みている状態 .ベッド中心部に布置した S3，S4 と昇降口付近に布置 したS5，S6に断続的に荷重変化が想定される。

(6) 端座位 被験者がベッドの端に着座し, 離床を試みている状態.S1〜S4 には出力がなく, 昇降口付近に布置 した S5，S6に荷重変化か想定される。離床寸前の姿勢なので，迅速かつ確実に判定しなければならない．

(7) 離床 被験者がベッドから完全に離床している状態. 全てのセンサに出力が認めらないことか想定される.な お，被験者が意識を失った状態や，心肺停止などの生命の危機にさらされている状態にもセンサの反応がな くなると考えられるが，このような状態の被験者には，心電計等のモニタリング機器が処置されていると考 えられるため, 本研究では判定対象外とする.

長座位は単に起き上がった状態で, 就寝状態に戻ることが考えられる . 続く, 短座位は昇降口に向かって体を回 転させるという動作を伴うため，被験者か離床に向けて行動を進めていると考えられる．よって，離床予測には， 長座位から短座位に移行した状態での判定が重要となる．更に，被験者か離床に向かって行動を進めて端座位と なった場合は, 離床寸前の姿勢なので, 迅速かつ確実に判定しなければならない.このように, 完全離床の前段 階で判定することて離床予測が実現され，転落や転倒などによる怪我や事故の防止に結び付けることができる．

\section{2 前処理}

計測された原信号にはノイズが含まれているため, 判別器に直接入力すると, 判定性能が低下するとともに, 計 算負荷の増加を招く．ノイズを取り除く方法として，閾值による処理が最も簡便でかつ一般的に使用されている． しかしながら, 閾値は主観的かつ経験的に設定されているため, 対象に応じたキャリブレーションや再設定が必 要となる．また，固定的に設定される閾值では，センサ自体の出力特性のバラつきを十分に吸収できない．更に， 人間を測定対象とする場合は, 個人差による影響を強く受ける．

個人差については, 被験者の体重を事前に設定する方式が一般的に採用されている(14) . 荷重の変化は被験者の 体重との関連性が高いと考えられるが, 男女差や年齢差などにより行動パターンが異なると考えられるため, 体 重だけではキャリブレーションが十分に行われるとは言い難い.一方, 本研究では, このような事前設定を必要 としない判定方法の構築を目指しており，被験者の違いによる個人差に対応するために機械学習を用いる．機械 


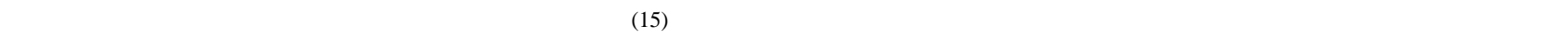
るデータのみから，被験者毎のパターンを学習することにより，閾值の設定を不要とする .

機械学習には樣々な種類の方式が提案されているが, 本研究では, データの類似性を自己学習することができ る自己組織化マップ (Self-Organizing Maps: SOM) ${ }^{(17)}$ を用いた . SOM は, 近傍と競合の概念に基づき, 教師なし 学習による自己写像特性によりデータの集合を形成する.SOM は，リモートセンシング, 顔画像処理, 文字認識， データマイニング等に用いられており, 実応用に対して有効性の高い性能を示すことが, 多数の研究を通じて検 証されている(18).

教師なし学習によるデータのクラスタリングには, k-means ${ }^{(19)}$ が幅広く用いられている . 一方 , SOM によるク ラスタリングは, k-means のような古典的クラスタリング法と比較して優位な性能を示すことが, Vesanto らの実 験により検証されている(20) . また , 寺島らは, k-means より SOM がクラスタリングにおいて誤認識率が最小とな ることを示している ${ }^{(21)}$.このため, 本研究においても SOM を用いた .

SOM のネットワーク構造を図 5 (a) に示す .ネットワークは , 入力層とマッピング層の 2 層から構成される . 入 力層は, 入力データの特徵次元に応じて, ユニットか割り当てられる . 本研究では, 6 個のパッドセンサを用いた ため，6 ユニットとした . 入力データを自己写像するマッピング層は , 低次元空間に配置されたユニット群から構 成される.本手法では, クラスタリングによるベクトル量子化として用いるため，マッピング層ユニットは 1 次元 に配置した . 入力データに対して , 、ッピング層のいずれかひとつのユニットが発火するように学習が行われる SOM の学習アルゴリズムを以下に示す . 時刻 $t$ における , 入力層ユニット $i(i=1, \ldots, I)$ から , マッピング層ユ ニット $p(p=1, \ldots, P)$ への結合荷重を $w_{i, p}(t)$ とする. 学習に先立ち, 乱数を用いて $w_{i, p}(t)$ を初期化する . $x_{i}(t)$ と $w_{i, p}(t)$ の類似度として , ユークリッド距離 $d_{j}$ を次式により算出する.

$$
d_{j}=\sqrt{\sum_{i=1}^{I}\left(x_{i}(t)-w_{i, p}(t)\right)^{2}} .
$$

$d_{p}$ が最小となるユニットを, 勝者ユニット $c$ として探索する.

$$
c=\operatorname{argmin}\left(d_{p}\right) .
$$

$c$ の近傍領域を $N_{s}(t)$ とすると，勝者ユニットとともに結合荷重を更新する対象となる.

$$
N_{s}(t)=S\left(1-\frac{t}{O}\right) \text {. }
$$

ここで, $S(0<S \leq P)$ は初期サイズ， $O$ は学習回数である . 次に,$N_{s}(t)$ の内部に位置する $w_{i, p}(t)$ を, 入力データ の特徵パターンに漸近するように，次式により更新する .

$$
w_{i p}(t+1)=w_{i, p}(t)+\alpha(t)\left(x_{i}(t)-w_{i, p}(t)\right) .
$$

ここで， $\alpha(t)$ は学習率係数であり，学習の進行とともに光の值を減少させる.$\alpha(t)$ の初期値を $A(0<A<1.0)$ と すると, 時刻 $t$ における係数は次式により与えられる .

$$
\alpha(t)=A\left(1-\frac{t}{O}\right) .
$$

学習の初期の段階では, $\alpha(t)$ を大きく取ることで, 結合荷重の更新幅を大きくし, 学習の進行を加速させる . 学 習の後半は, 係数を小さくすることで, 学習を収束に向けている.

学習時は, ランダムサンプリングにより学習データを取り出して，Oに達するまで上記の学習処理を繰り返す． 学習終了後に, 学習データを再度 SOM に入力し, 発火するユニットを特定する. 発火ユニットが关の学習データ に与えられるラベルとなり，同一のラベルを有するユニットが同一の集合を形成する．ここで, 圧電素子を用いる 本センサでは, 荷重変化が生じないときは才フセット付近の電圧值が出力され，この值を示す区間が相対的に多く なる .このため, マッピング層ユニットにおいて , 最もデータか㳔応付くユニットの出現が予測される .このユ ニットに対応付くデータを取り除くことにより，荷重変化がないデータを判定対象外に振り分けることができる． 
Table 2 Setting values of parameters on SOM and CPN.

\begin{tabular}{c|c|c|c|c|c|c|c|c}
\hline Method & I [unit] & J [unit] & P [unit] & Q [unit] & S [unit] & A & B & O [epoch] \\
\hline SOM & 6 & - & 20 & - & 16 & 0.5 & - & $1,000,000$ \\
\hline CPN & 6 & 7 & 20 & 20 & 16 & 0.5 & 0.8 & 100,000 \\
\hline
\end{tabular}

\section{$3 \cdot 3$ 判定方法}

ノイズを取り除いたデータに対して，教師あり学習を用いて離床行動を判定する．教師なし学習は情報表現の 学習 ${ }^{(23)}$ であるのに対して, 教師あり学習は写像関係を構築する学習 ${ }^{(22)}$ である. 教師あり学習には, カーネル関数 による高次元空間への写像により高い識別性能を有するサポートベクタマシン (Support Vector Machines: SVM) や弱学習器を大量に組み合わせたブースティングなどが有名である .一方, 本研究では, SOM を教師あり学習に 拡張した対向伝搬ネットワーク (Counter Propagation Networks: CPN) ${ }^{(24)}$ を用いた .

SVM やブースティングではなくCPN を用いた理由は，1) 前処理で使用する SOM に Grossberg 層を追加するだ けの学習アルゴリズムのため実装が容易であること，2) 写像構造を形成する過程でデータ間の関係性が可視化で きる，という特長を有することによる. 学習アルゴリズムは, SOM との差分のみを数式で示す . データ間の関係 性の可視化は，カテゴリマップにより実現される ${ }^{(18)}$. 可視化結果は，評価実験において図を用いて具体的に示す．

Nilsen によって提案された CPN は, SOM に教師信号が入力される Grossberg 層を追加した構造になる ${ }^{(24)}$. CPN のネットワーク構造を図 5 (b) に示す . ネットワークは , 入力層とマッピング層は SOM と同樣であり , マッピン グ層に対して , 入力層と対向するように Grossberg 層のユニットか配置される . なお , 本研究では, マッピング層 は，データ間の類似性を可視化するために，2 次元構造とした .

CPN の学習アルゴリズムを以下に示す . 入力データの提示から勝者ユニットの探索し結合荷重を更新するまで アルゴリズムは, SOM と同じ処理手順となる .ただし , マッピング層を 2 次元としているので, 結合荷重と近傍 領域は，光れ攵れ， $w_{i, p, q}(t)(p=1, \ldots, P, q=1, \ldots, Q)$ と $N_{p, q}(t)$ になる . 次に, Grossberg 層ユニット $j$ から $(p, q) へ$ の結合荷重を $v_{j, p, q}(t)$ とする.$N_{p, q}(t)$ の内部の結合荷重 $v_{i, p, q}(t)$ は, Grossberg の学習アルゴリズムで㳄式により 更新される.

$$
v_{j, p, q}(t+1)=v_{j, p, q}(t)+\beta(t)\left(T_{j}(t)-v_{j, p, q} j(t)\right) .
$$

ここで, $T_{j}$ は教師信号である $\beta(t)$ は $\alpha(t)$ と同樣，学習率係数であり，学習の進行とともに光の值を減少させる. $\beta(t)$ の初期值を $B(0<B<1.0)$ とすると，時刻 $t$ における係数は次式により与えられる .

$$
\beta(t)=B\left(1-\frac{t}{O}\right) \text {. }
$$

最後に , Grossberg 層のユニット $j$ に対する $v_{j, p, q}(t)$ の最大值として , 次式によりラベル $l_{j}(t)$ を探索する.

$$
l_{j}(t)=\underset{1 \leq j \leq J}{\operatorname{argmax}}\left(v_{j, p, q}(t)\right) .
$$

全てのユニットのラベルを決定することにより，カテゴリマップが生成される.学習により構筑した判別器に対し て , テストデータを入力する . テストデータと特徵パターンの類似度 , すわなちユークリッド距離が最小となる マッピング層のユニットが発火する．弚のユニットに対応付くラベルがCPN の判定結果となる .

\section{4. 実 験 結 果}

\section{$4 \cdot 1$ 実験条件}

臨床現場を模した実験環境を構築し，提案システムの評価実験を実施した。評価に用いたベッドを図 3 (a) に示 す.被験者は 3 名（被験者 $\mathrm{A} \sim \mathrm{C}$ ) とした，属性情報として，各被験者の体重は，被験者 $\mathrm{A}$ が $70 \mathrm{~kg}$ 台，被験者 $\mathrm{B}$ が $60 \mathrm{~kg}$ 台，被験者 C が $50 \mathrm{~kg}$ 台である.各被験者は 7 パターンから成る一連の動作を 6 回繰り返した．よって， 被験者毎に 6 通りのデータを取得した . 各姿勢の動作は 20 秒毎に切り替えた . データ取得のサンプリングレート は $50 \mathrm{~Hz}$ とした .

$\mathrm{SOM}$ と CPN に設定したネットワークのパラメータを表 2 に示す. 設定値は, 著者らの従来研究 ${ }^{(25)}$ と細川らの 研究報告 ${ }^{(26)}$ に基づいて決定した . 判定結果の評価には，交差検定法 ${ }^{(27)}$ を用いた . 本実験では，6通りのデータを， 


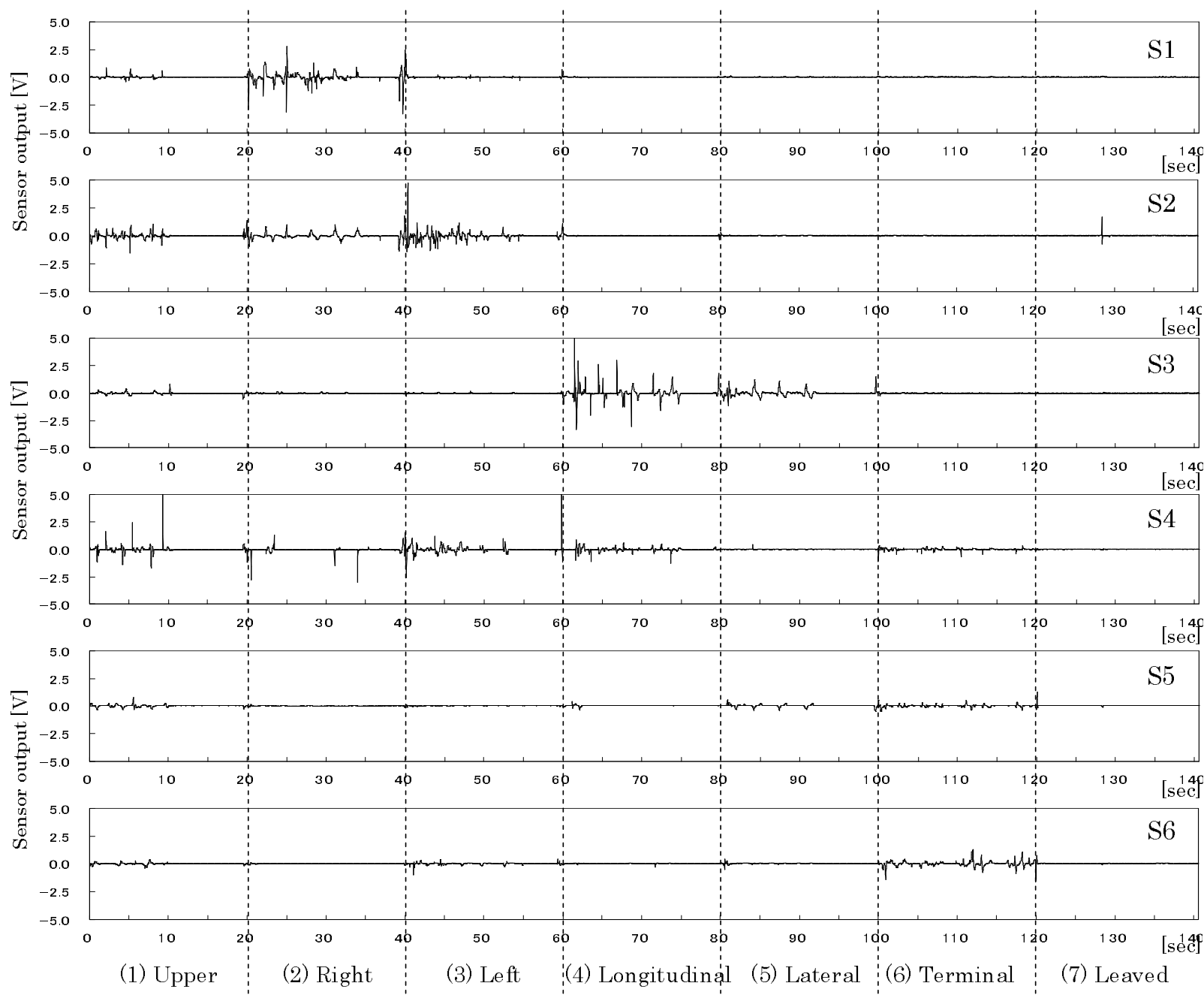

Fig. 6 Time-series changes of sensor output in each behavior pattern (Subject A, First trial).

学習用に 5 データ, テスト用に 1 データに分割して判定した よっって，学習データとテストデータで 6 通りの組 み合せを作成して評価できる .

$4 \cdot 2$ 計測データ

センサの出力值の時間推移を図 6 に示す. 縦軸は圧電素子の出力電圧, 横軸は時間となる . 図中の点線は, 姿 勢の区切りを示している . 就寝状態から起き上がった状態の長座位, ベッドの昇降口方向に体を回転させた短座 位, 乥して離床直前の端座位と推移するにつれて, 信号の出力パターンが変化している．

就畠状態の仰臥位と左右の側臥位では，S1〜S4 の出力か確認される . S5 と S6 は若干のノイズが出力されてい るものの，S1〜S4 のような顕著な出力は確認されていない . 長座位では S3 において電圧が高くなっている . 起 き上がる動作に伴って，体重が榍部に集中するためと考えられる．端座位では S1〜S3 には出力はなく，S5 と S6 に出力が確認される . また , S5 に近いS4 にも若干の出力が確認される. 完全離床後は, 全てのセンサからの出 力は確認されない .

以上の出力パターンは, 被験者 $\mathrm{A}$ の 1 回目の試行である . 信号の出力パターンや強度は, 試行毎, 被験者毎に 異なる .このため，信号波形のみからノイズの除去や判定のための閾値を決定することは困難な課題である . 一 方, 機械学習を用いる本手法では, 以降の処理は全て自動で実行される. 


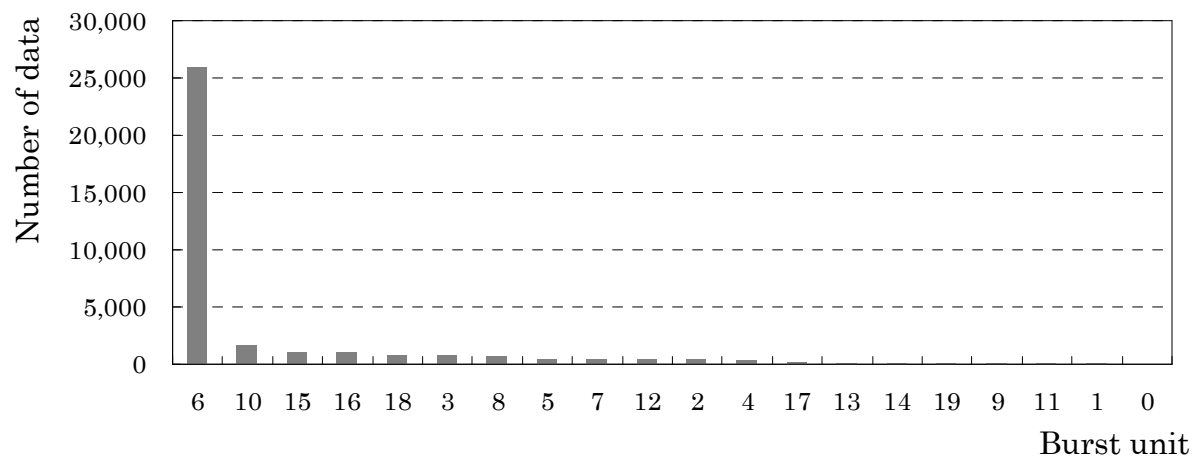

Fig. 7 Histogram of classfication results obtained using SOM.

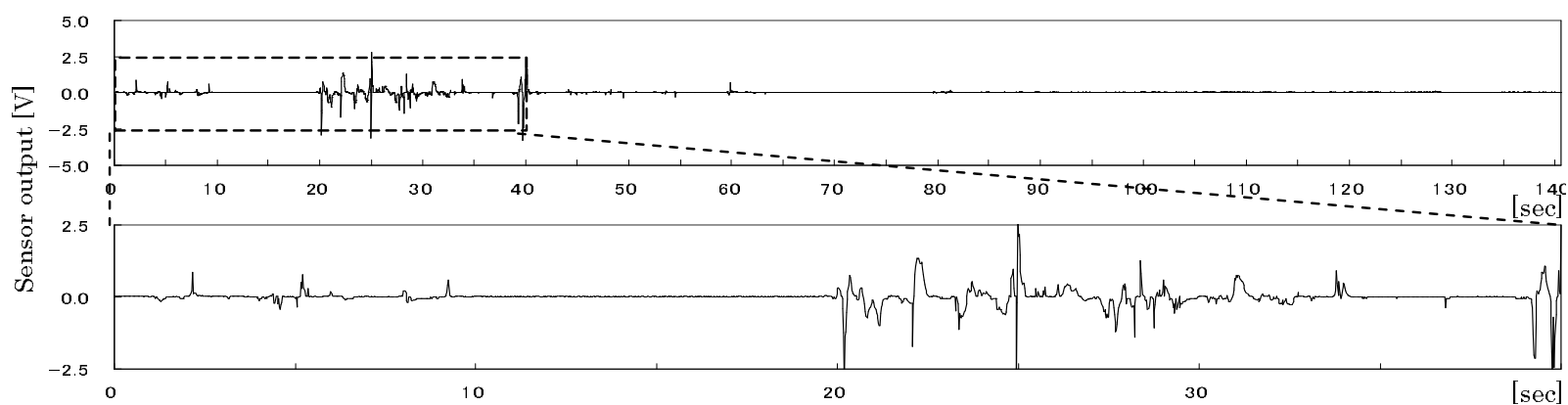

(a) Original sensor output signals

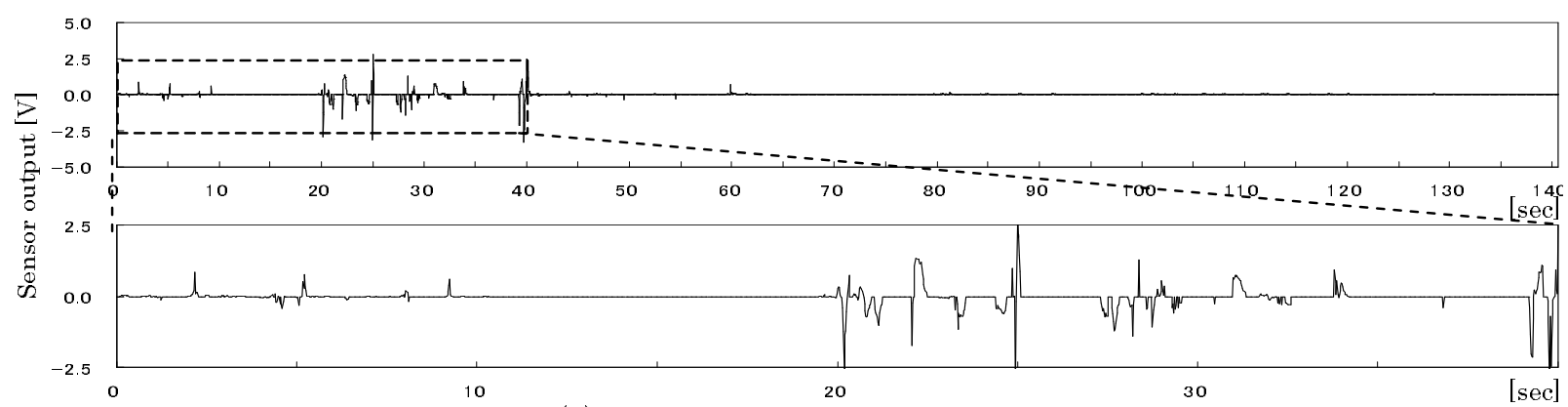

(b) After removing noise using SOMs

Fig. 8 Output voltage from S1 before and after removing nosing signals that contain in the 6th unit.

\section{$4 \cdot 3$ ノイズ除去結果}

判定精度の向上と処理負荷の低減を目的として，本手法ではSOM を用いてノイズとなるパターンを除去した． SOM による学習データのクラスタリング結果を図 7 に示す. 横軸は発火したユニット番号 , 縦軸は各ユニットに 対応付くデータ数 (発火回数) となる.ユニットの番号は, 発火回数が多い順に左側から並び替えている. 圧電 素子は荷重変化がない場合は電圧を出力しないため, 図 6 に示すように大半はオフセット付近の電圧変化となる . 図 7 では，6 番目のユニットが該当する.この場合では，34,976 データに対して 25,954 データが対応付いている . 全データに対して , 6 番ユニットの占める割合は, $74.2 \%$ はる . なお，残りの $15.8 \%$ の゙ータは, ロングテール 状に対応付けられている．ユニット数を増減させた場合にも，同樣の傾向を示すことを確認している．

6 番ユニットに対応付くデータを取り除いた信号波形を図 8 に示す.また，S1 の前半 40 秒間の拡大波形を，処 理前後の結果の下側に表示している.オフセット付近の微小なノイズが取り除かれていることが, 視覚的にも確 認できる .

\section{4 判定結果}

判別器として構築した被験者別のカテゴリマップを図 9 に示す . カテゴリマップ上の数值は, 学習によりラベル 付けされた姿勢を示す. 被験者 $\mathrm{A}$ は, 就寝中の姿勢に対応するラベル 1 〜 がマップの外側に分布している. 端座 


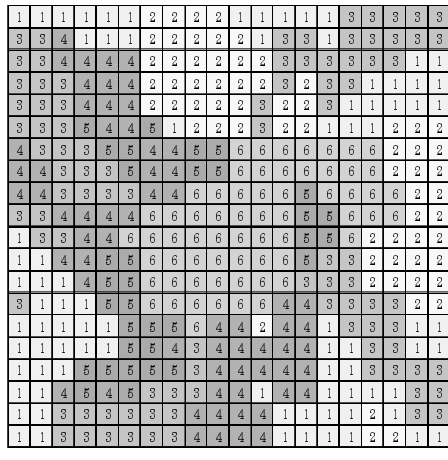

(b) Subject A

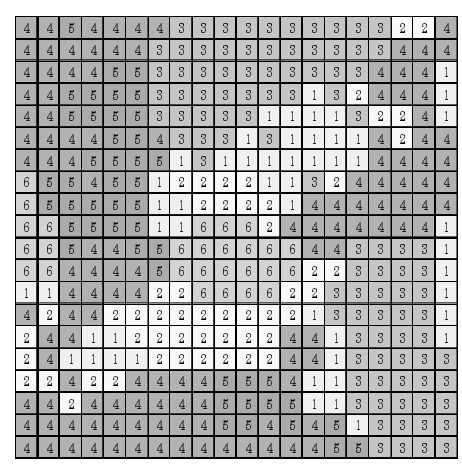

(b) Subject B

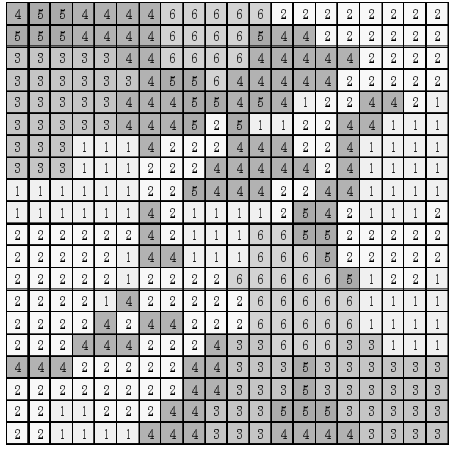

(b) Subject C

Fig. 9 Categrory maps in each subject. The grids correspond to the units on the mapping layer of CPNs. Lavels 1-7 denote the positions of upper sleeping, rolled right side, rolled left side, longitudinal sitting, lateral sitting, terminal sitting, and completely laved from the bed..

Table 3 Recognition accuracies of respective subjects and positions [\%].

\begin{tabular}{c|c|c|c|c|c|c|c|c}
\hline Subject & Upper & Right & Left & Longitudinal & Lateral & Terminal & Leaved & Average \\
\hline A & 100 & 83.3 & 66.7 & 83.3 & 16.7 & 100 & 100 & 78.6 \\
\hline B & 83.3 & 100 & 100 & 100 & 0 & 100 & 100 & 83.3 \\
\hline C & 0 & 33.3 & 100 & 100 & 100 & 83.3 & 100 & 73.8 \\
\hline Average & 61.1 & 72.2 & 88.9 & 94.4 & 38.9 & 94.4 & 100 & 78.6 \\
\hline
\end{tabular}

位のラベル 6 は中心付近に単一のクラスタが形成されている . ラベル 6 を取り囲むように , 長座位のラベル 4 と 短座位のラベル 5 が , マップの左側と下側を中心に分布している.被験者 $\mathrm{B}$ は , マップの左側にラベル 4 6が分 布している. ラベル 4 の分布が相対的に広く, 右上部にも分布している. ラベル 1〜3の分布は, ラベル 4 と 6 に より，大きく2つの集合に分かれている . 被験者 C は，いずれのラベルも複数の分布を示している .このように， 姿勢の変化による各センサにおける信号の分布は, 被験者毎に異なっていることが, カテゴリマップから観察で きる .

次に , テストデータをカテゴリマップに入カし，発火したユニットに対応付くラベルから姿勢を判定した . 判 定結果を表 3 に示す. 交差検定により 6 通りの組み合わせについて評価した . 判定率は, 姿勢が切り替わる 20 秒 で最も反応回数が多かったラベルと事前に設定した正解データが一致した割合から算出した .

被験者 3 名の平均判定率は 78.6\%であった . 被験者別では, 被験者 B が最も高く $83.3 \%$ ，被験者 C が最も低く 73.8\%であった . 姿勢別では, 離床は $100 \%$ の判定率となっている. 離床予測において重要な判定対象となる長座 位と端座位は $94.4 \%$ と高い判定率になっているものの，短座位は $38.9 \%$ に留まっている.被験者別では，被験者 C は 100\%の判定率となっているが, 被験者 B は 0\%, 被験者 A は $16.7 \%$ と著しく低いため, 短座位は個人差による 影響が大きい姿勢であると考えられる．就寝姿勢では，仰臥位より左右の側臥位の判定率が高い . これは，仰臥 位では上半身の荷重がS1〜S4 のセンサに分散するのに対して，側臥位では左右の 2 個ずつのセンサに荷重が集中 したためと考えられる .

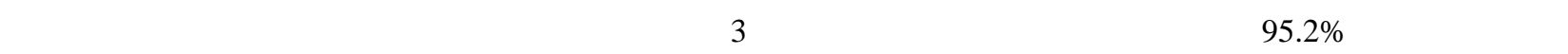
究では判定対象を 7 パターンとしたが, 実際に臨床現場では 3 パターンでも有用性が高いため, 実応用に資する 結果であると考えている .

\section{5 考察}

表 4 に示す混同対照表を用いて，誤判定について分析する．混同対照表では，判定に成功したデータ数が対角 線上に表示される.表中では下線で示している. 誤判定のデータ数と姿勢の名称は, 横方向を基準として縦方向 のラベルを参照することで特定できる．

判別率が著しく低かった短座位は, 正解が 7 データのみで, 長座位に 8 データ, 端座位に 3 データか誤判別さ 
Table 4 Confusion matrix of respective positions. Underlines show the numbers of correct data.

\begin{tabular}{c|c|c|c|c|c|c|c}
\hline Position & Upper & Right & Left & Longitudinal & Lateral & Terminal & Leaved \\
\hline Upper & $\underline{11}$ & 1 & 5 & 1 & 0 & 0 & 0 \\
\hline Right & 1 & $\underline{13}$ & 0 & 4 & 0 & 0 & 0 \\
\hline Left & 2 & 0 & $\underline{16}$ & 0 & 0 & 0 & 0 \\
\hline Longitudinal & 0 & 1 & 0 & $\underline{17}$ & 0 & 0 & 0 \\
\hline Lateral & 0 & 0 & 0 & 8 & $\underline{7}$ & 3 & 0 \\
\hline Terminal & 0 & 0 & 0 & 1 & 0 & $\underline{17}$ & 0 \\
\hline Leaved & 0 & 0 & 0 & 0 & 0 & 0 & $\underline{18}$ \\
\hline
\end{tabular}

れた . 長座位から短座位は, 上半身が 90 度回転するため, 被験者の姿勢は大きく異なる .この際のパッドセンサ に加わる荷重は，両座位とも被験者の殽部のベッド中心付近に集中するため，両者の判別が難しかったと考えら れる.一方，長座位を短座位として誤判別したデータは存在しない.ベッドの昇降口付近に脚部の荷重が集中す る短座位は，端座位との境界も曖昧なことから，誤判別に結びついたと考えられる．しかしながら，短座位を仰 臥位，左右の側臥位，あるいは離床として誤判別していないため，離床予測においては致命的なエラーにはなら いと考えられる．

次に誤判別が多かった仰臥位は，表 4 の 2 段目に示す通り，1 データが長座位，6 データが左右の側臥位に誤判 別された . 側臥位は離床行動ではないため, 仰臥位での誤判別は, 1 データを除いて就寝状態での姿勢に留まって いる．一方，右臥位は，4データが長座位として誤判別されている．右臥位では，主に S 1 と S3 に荷重が集中す るが，被験者によってはS3 に荷重が偏ったことが原因と考えられる．

従来手法との比較では , 初雁らのアクチュエータに内蔵したひずみゲージによる離床センサは , 長座位が $87.7 \%$ ， 端座位が $98.1 \% の$ 検知率と報告されている ${ }^{(14)}$. 実験環境や被験者数は異なるが，本結果の判定精度は，端座位で $3.7 \%$ 劣るものの，長座位は $6.7 \%$ 上回る結果となっている.なお，初雁らの方式は 3 段階の体重設定が必要なこと と, 判定対象が長座位, 端座位, 完全離床の 3 パターンのみに留まっているため, 機能面においても本手法は優 位性があると考えている .

\section{5.お わりに}

本論文では，離床行動を予測するための非拘束のセンサシステムを提案した . 圧電素子を用いたパッド形状の荷 重センサを提案するとともに , 測定データを取得するためのマイコンボードの回路ならびにモニタリングシステ ムを開発した . また，センサから得られるデータから，離床及ひ離床予測に結びつく被験者の姿勢を，機械学習に より判定する方式を開発した。臨床環境を模した実験環境において，3 名の被験者を対象としてデータを取得し， 提案手法の有用性を検証した . 光の結果，7パターンの姿勢に対して，平均で $78.6 \%$ 判定率が得られた . 特に， 離床予測に結びつく長座位と端座位は $94.4 \%$ の判定率が得られ，離床予測における有効性の高い結果が得られた 。

今後は，被験者数を増加させて，本手法の適用範囲を広げるとともに，安定した検出と再現性を確保したい，ま た，介護施設や独居高齢者宅での被介護者の QOL とプライバシを確保しつつ，安心・安全を見守る生活モニタリ ングシステムへの発展を目指したい .

謝 辞

臨床現場における専門知識の提供と評価方法についてこ指導をいただきました秋田大学医学部高橋正人医師に 感謝申し上げます．また，データ取得に協力してくれた 3 名の被験者に感謝いたします．

$$
\text { 文献 }
$$

（1）国立社会保障・人口問題研究所，日本の将来推計人口，(2012) .

（2）山田楼子，高島幹子，佐藤幸美，伊藤亘，伊藤登茂子，浅沼義博“" 転倒・転落に伴うインシデント事例の検討と対策 -発 生構造に基づいた分類法を用いて-”，秋田大学大学院医学系研究科保健学専攻紀要，Vol.18，No.2 (2010)，pp. 144-150.

（3）今泉一哉，岩上優美，山下和彦 “" 高齢者の健康支援のためのモニタリングシステムの有用性”，IT ヘルスケア，Vol.5， No.1 (2010) , pp.63-64 . 
（4）松田啓史，山口彰一，荒川忠洋 “ 高齢者生活行動モニタリングシステム”，松下電工技報，Vol.82 (2003), pp.4-8 .

（5）辰巳智子，金本恵子，八木尚美 “ 転倒むしの効果的な使用方法-誤作動しない紐の長さと身長の検討をして”，日本看護 学会論文集, Vol.38 (2007), pp.144-146.

（6）近藤澄子, 神谷千代, 宮木晴美, 鳥山夕子, 三村恵美, 土田文子 “離床センサーマット使用による転倒・転落予防の有 効性”, 日本農村医学会雑誌, Vol.55, No.3 (2006) pp.245 .

（7）春山和男, 田中幹也, 小林茂樹, 安岡克典, 内堀晃彦, 岡正人 “; 電灯線通信とマット・センサーを用いた離床検知通報 装置の開発”, 電学論 D , Vol.126, No.11 (2006), pp.1507-1513.

（8）田中稔彦 “ フィンランド製超高感度感圧センサによる生体信号モニタリング技術の独居老人対応遠隔監視の活用事例”， 日本遠隔医療学会誌, Vol.3，No.2(2007)，pp.231-233.

(9) 関弘和，堀 洋一 “ 高齢者モニタリングのためのカメラ画像を用いた異常動作検出 ” ，電学論 D，Vol.122，No.2 (2002), pp.1-7.

(10) 株式会社東京センサ “ PIEZO FILM technical manual ” , Vol.10, Rev.1 (2001), pp.17-18 .

（11）清水雅年，菅原協子，尾崎文恵，浜善博，西村三千雄，吉野裕教，“超音波アレイセンサを用いた離床検出システムの開 発 (Part 3)" , ライフサポート学会誌, Vol.21, No.3 (2009), pp.9-16 .

(12) 平澤桂一，松村成宗，金丸直義，阿部匡伸 “病院・介護施設における転倒転落事故予防システム”，NTT 技術ジャーナ ル, Vol.20, No.1 (2008), pp.32-35 .

(13) 上薗岡, 久保敦, 中城親男, 上加世田晃一, 内田猛俊 “離床予測システムの実用化研究”, 鹿児島県工業技術センター 研究成果発表会予稿集 (2010), pp.34-35.

(14) 初雁卓郎, 椎野俊秀, 村井真也 “ ベッド上の患者行動を推定・通知するシステム「離床 CATCH」の提案”, 労働科学 , Vol.88, No.3 (2012), pp.94-102.

(15) 中村和晃, 角所考 , 村上正行 , 美濃導彦“ ” e-learning における学習者の顔動作観測に基づく主観的難易度の推定”，電子 情報通信学会論文誌 D, Vol.J93-D, No.5 (2010), pp.568-578 .

（16）茂木学，松村成宗，山田智広，武藤伸洋，金丸直義，下倉健一朗，阿部匡伸，森田佳子，葛西圭子 “転倒転落事故予防 に向けた入院患者の起き上がり動作分析 (第 2 報)”，日本医療マネジメント学会誌，Vol.12，No.1 (2011)，pp.25-29．

(17) Kohonen, T., Self-Organizing Maps, Springer Series in Information Sciences, (1995).

(18) 山川烈, 徳高平蔵, 藤村喜久郎, 自己組織化マップ応用事例集-SOMによる可視化情報処理, 海文堂出版，(2002).

(19) McQueen, J., "Some Methods for Classification and Analysis of Multivariate Observations", Proceedings Fifth Berkeley Symposium on Mathematical Statistics and Probability, (1967), pp.281-297.

(20) Vesanto, J. and Alhoniemi, E., "Clustering of the Self-Organizing Map”, IEEE Transactions of Neural Networks, Vol.11, No.3 (2000), pp.586-600.

(21) 寺島幹彦, 白谷文行, 山本公明 “自己組織化特徵マップ上のデータ密度ヒストグラムを用いた教師なしクラスタ分類法”, 電子情報通信学会論文誌 D-II ，Vol.J79-D-II，No.7 (1996)，pp.1280-1290．

(22) 銅谷賢治 “ 計算神経科学への招待-脳の学習機構の理解を目指して (第 4 回) 教師あり学習”, 数理科学, Vol.43, No.10 (2005), pp.67-74.

(23) 銅谷賢治“” 計算神経科学への招待-脳の学習機構の理解を目指して (第 8 回) 教師なし学習”, 数理科学, Vol.44, No.3 (2006), pp.77-83.

(24) Nielsen, R.H. , “Counterpropagation networks”, Proceedings of IEEE First International Conference on Neural Networks, (1987).

(25) Tsukada M., Utsumi Y., Madokoro H., and Sato K., "Unsupervised Feature Selection and Category Classification for a VisionBased Mobile Robot”, IEICE Transactions of Information \& Systems, Vol.E94-D, No.1 (2011), pp.127-136.

（26）細川直史，伊藤陽介，星仰，自己組織化マップによる多偏波 SAR データからの市街地特性の抽出，電子情報通信学会論 文誌 B ，Vol.J84-B，No.6(2001)，pp.1043-1051。

(27) Kohavi, R., “A study of cross-validation and bootstrap for accuracy estimation and model selection”, Proceedings the Fourteenth International Joint Conference on Artificial Intelligence, Vol. 2, No.12 (1995), pp.1137-1143. 